\title{
DECENTRALIZED COMPOSTING OF MUNICIPAL SOLID WASTE IN BENGALURU CITY - AN OVERVIEW
}

\author{
Pavan $^{1}$, H B Balakrishna ${ }^{2}$ \\ ${ }^{1}$ Assistant Professor, Department of Civil Engineering, Sir M Visvesvaraya Institute of Technology, Bangalore. \\ ${ }^{2}$ Professor, Department of Civil Engineering, Bangalore Institute of Technology, Bangalore
}

\begin{abstract}
Bengaluru city is facing problem with municipal solid waste management, the centralized composting units established outskirts the city have failed to manage the waste due to enormous quantities of mixed waste dumped there, and one of the composting unit has also been issued High court orders to close down. In this paper, two of the successful decentralized composting units in Bengaluru are analyzed and the feasibility of replicating the same at the city level is worked out.
\end{abstract}

Keywords: Community initiatives, Decentralized composting, Municipal Solid Waste management, Replicability.

\section{INTRODUCTION}

Municipal solid waste management is the management of generation, storage, collection, transfer and transport, processing and disposal of solid wastes in an environmentally compatible manner with due considerations of the principles of economy, aesthetics, energy and conservation [1]. Municipal solid waste is a potential resource of organic materials, which can be processed into compost or bio-fertilizer or biogas, some items of trash, can be salvaged, recycled and reused. Municipal solid waste (MSW) in Bengaluru contains a large organic fraction ranging from $30-50 \%[2]$. This organic fraction tends to decompose leading to smell and odor problems. Among the known processing technologies for organic waste, "composting" is quite common and it results in production of a stable product that is, compost, that can be used as a manure and soil conditioner on farms and orchards. The process is important, as it results in conservation of natural resources. After the waste is composted, only the nondecomposable fraction remained is to be disposed off in landfill, thus, the land requirement which is a critical component and is in short supply in urban centers, is substantially reduced leading to overall economy.

Decomposition of organic waste is a natural phenomenon. Composting is an organized method of producing manure by adopting this natural phenomenon. Composting refers to controlled process involving microbial decomposition of organic matter [3]. A various composting schemes of different scale, type and organizational structure currently exist in the country, a general overview is lacking and very little independent site-specific information is available. The objective of the study is to document the innovative decentralized practices in managing the municipal solid waste with emphasis on quantity and types, total waste generated, quantity of compost prepared, institutional arrangements, and financial aspects to analyze the feasibility of replicating more of those innovative practices by the waste management authorities in Bengaluru city.

\section{MATERIALS AND METHODS}

The two of the decentralized plants were closely studied for a period of six months to understand the efficiency in source segregation, collection mechanism, resource recovery, technical aspects of composting and final disposal of rejects. The physical composition of the waste was found out by hand sorting and visual methods. The institutional aspects, financial aspects and social aspects were also consolidated. Then the information was further analyzed in terms of sustainability, replicability and effective utilization for city level.

\section{RESULTS AND DISCUSSION}

The Bengaluru city generates a total of around 5000tons of municipal solid waste everyday, out of which $30-50 \%$ constitutes organic waste [3]. The various sources of municipal organic wastes are houses (single and multi dwellings), hotels and restaurants, religious places, marriage and function halls, markets, juice centers and cafeterias, hostels, road side vendors, educational institutions with canteen and hostel facilities, slaughter houses, organic waste from medical facilities, greenery along road side, meat and mutton markets, parks, human and animal carcasses. Even though the contractual terms mandates separate collection of organic, dry waste and sanitary waste, there will be only one collection vehicle collecting all the types of waste together. There are only few fractions of the people doing source segregation but it gets mixed up in the collection vehicle. Bangalore has six wastes processing cum landfilling centers, now hearing to Public Interest Litigation that the contractor in charge of Mavallipura has failed in his obligation to process the waste; it is closed down [4]. In the waste processing plant at Mandur north, the villagers protested the dumping of mixed garbage, which created havoc in the city for almost a month [5]. In view of the prevailing situations, it is high time that the waste management authorities consider decentralized waste processing centers to manage the waste effectively. The various aspects in which 
decentralization of waste management proves to be effective as compared with centralized composting is as discussed in Table 1.

Table-1: Comparison of centralized and decentralized solid waste management system

\begin{tabular}{|c|c|}
\hline Centralized & Decentralized \\
\hline High transport cost & Minimal transport cost \\
\hline $\begin{array}{l}\text { High } \\
\text { pollution }\end{array}$ & $\begin{array}{l}\text { Minimal } \\
\text { pollution }\end{array}$ \\
\hline $\begin{array}{l}\text { High dependence on } \\
\text { transport contractors }\end{array}$ & No such problem \\
\hline Large farmlands used & $\begin{array}{l}\text { Small waste } \\
\text { management centers in } \\
\text { wards }\end{array}$ \\
\hline $\begin{array}{l}\text { Dependence on one } \\
\text { technology }\end{array}$ & $\begin{array}{l}\text { Multiple methods } \\
\text { yielding best value }\end{array}$ \\
\hline $\begin{array}{l}\text { No individual } \\
\text { responsibility }\end{array}$ & $\begin{array}{l}\text { Ownership and } \\
\text { awareness among public }\end{array}$ \\
\hline $\begin{array}{l}\text { What next after plant } \\
\text { reaches capacity }\end{array}$ & $\begin{array}{l}\text { Scalable in every } \\
\text { existing and new layout }\end{array}$ \\
\hline $\begin{array}{l}\text { Large upfront capital } \\
\text { investment }\end{array}$ & $\begin{array}{l}\text { Smaller investments as } \\
\text { and when required }\end{array}$ \\
\hline $\begin{array}{ll}\text { Polluting } & \text { someone } \\
\text { else's land } & \end{array}$ & $\begin{array}{l}\text { Manage locally without } \\
\text { creating pollution }\end{array}$ \\
\hline $\begin{array}{l}\text { Complete dependence } \\
\text { on a system }\end{array}$ & $\begin{array}{l}\text { Localized control of } \\
\text { situation }\end{array}$ \\
\hline Mixed garbage disposal & $\begin{array}{l}\text { Waste } \\
\text { management }\end{array}$ \\
\hline $\begin{array}{l}\text { Reduced } \\
\text { recovery }\end{array}$ & $\begin{array}{l}\text { Maximum } \\
\text { recovery }\end{array}$ \\
\hline $\begin{array}{l}\text { No guarantee it will } \\
\text { work }\end{array}$ & $\begin{array}{l}\text { Multiple } \\
\text { methods }\end{array}$ \\
\hline $\begin{array}{l}\text { Low employment } \\
\text { opportunities }\end{array}$ & $\begin{array}{l}\text { Localized employment } \\
\text { opportunities }\end{array}$ \\
\hline
\end{tabular}

The specialty of Bengaluru is that there are various nongovernment organizations, which are working at small scale for complete cleaning and disposal of waste in small manageable areas. In this study the Godrej Woodsman Apartment (GWA), an economically high-end apartment with high income to medium- high- income people residing, is located in ward No.7-Byatarayanapura of Yelahanka zone. A total of 849 houses are present, out of which around 600 are occupied. The municipal solid waste is source segregated as wet waste, dry waste and sanitary waste by the residents. The house keeping-staff collect the waste in trolley type Otto bins of 100ltr capacity. The percentage of source segregation followed by the residents is $50 \%$ hence secondary segregation is done before processing. Per day about $94 \mathrm{~kg}$ of organic compostable waste, $42 \mathrm{~kg}$ of sanitary waste, and $135 \mathrm{~kg}$ rejects (this also include non-compostable waste such as coconut shell, mango seeds etc.) are generated. About 0.6tons of garden trimmings, 1.12 tons of construction debris (obtained during remodeling works) is generated monthly. The recyclables, rejects and construction debris are sold once in a week to a recycler who purchases all types of recyclable waste on a lump-sum contract basis. The Sanitary waste is handed over to a bio-medical waste contractor at the rate Rs. 40,000 per year. The segregated compostable organic waste is mixed with previously prepared compost to maintain optimum moisture content, which is approximately $40-50 \%$ of the days' waste. Then it is fed to the organic waste composter machine, and run for 15-20 min. The two main objectives of using Organic waste composter is to mix and shred the waste properly and secondly heat is generated inside which kills all the pathogenic microorganisms; in a nutshell the thermophilic phase of composting is hastened. Then the waste is filled into plastic crates and arranged in rows for further maturation. Water sprinklers are attached at each row to spray water mechanically. The excess water is collected by the tray arrangement at the bottom of each row. The windows are mesh covered; hence the room is properly ventilated. The composting duration for a batch of fresh waste is one month. Then they are stored in plastic drums till further usage. The compost recovery that can be obtained from compostable organic material is about 35\% compared to the compost recovery of $18 \%$ from mixed waste at centralized processing centers [7]. The quantities of waste generated in Godrej Woodsman apartment from December, 2013 to June, 2014 is presented in chart 1 to Chart 4.

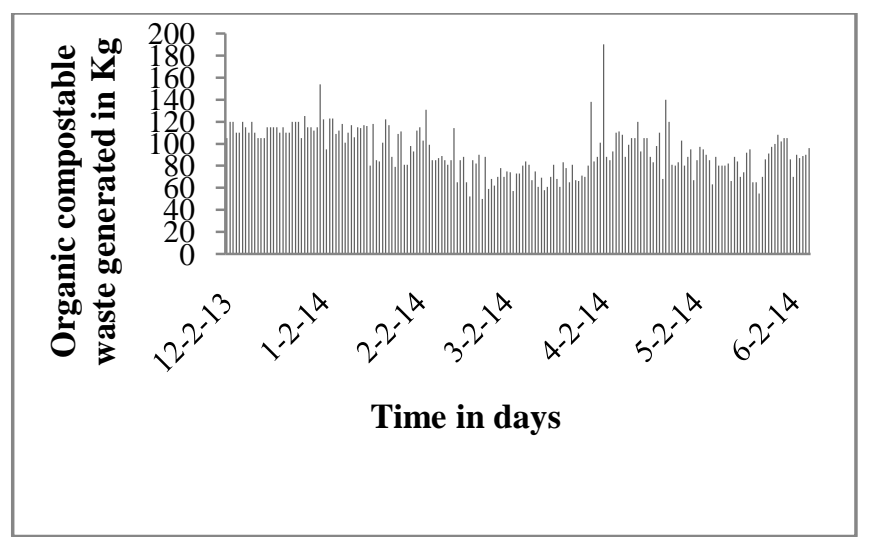

Chart -1: Compostable organic waste generation in GWA.

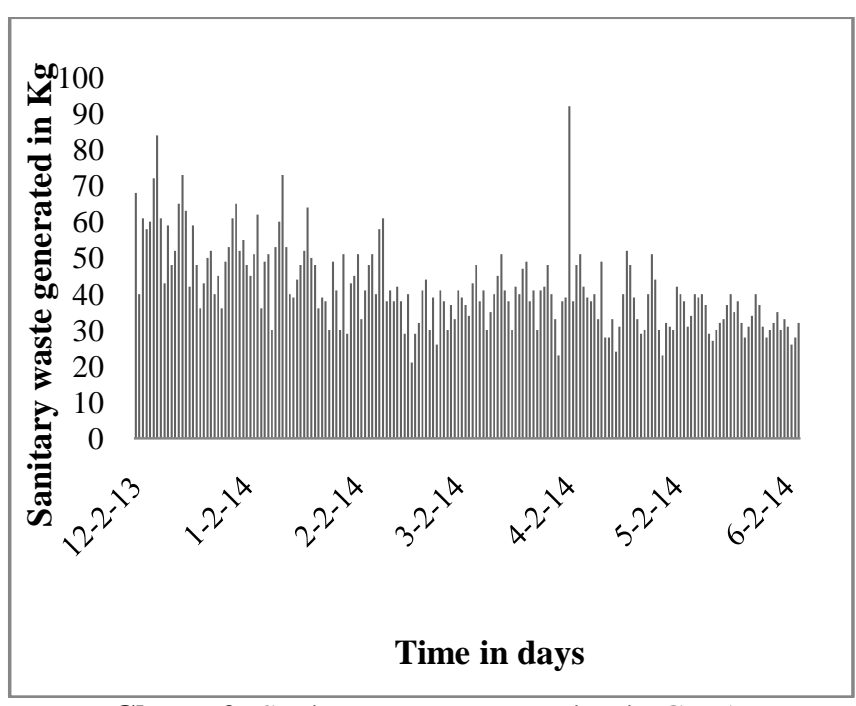

Chart- 2: Sanitary waste generation in GWA 


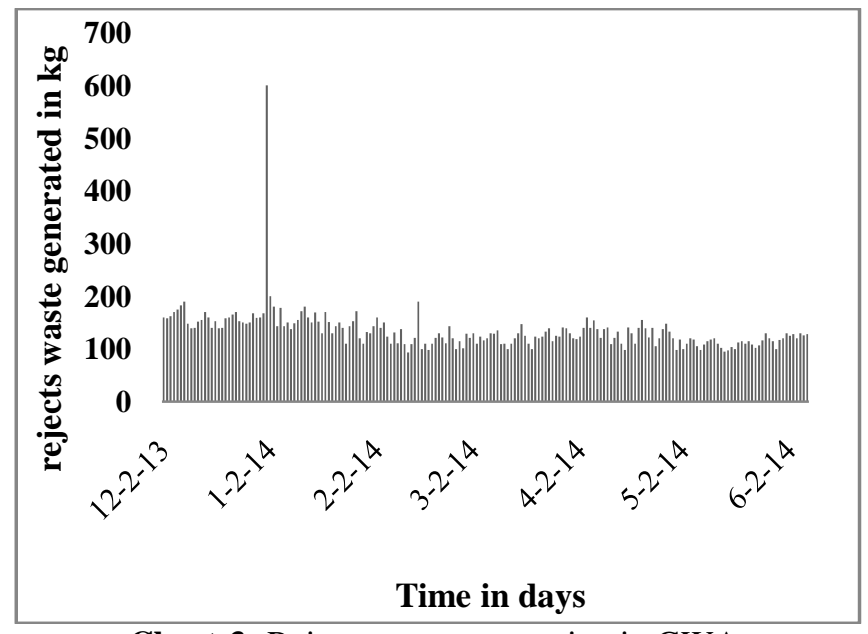

Chart-3: Rejects waste generation in GWA

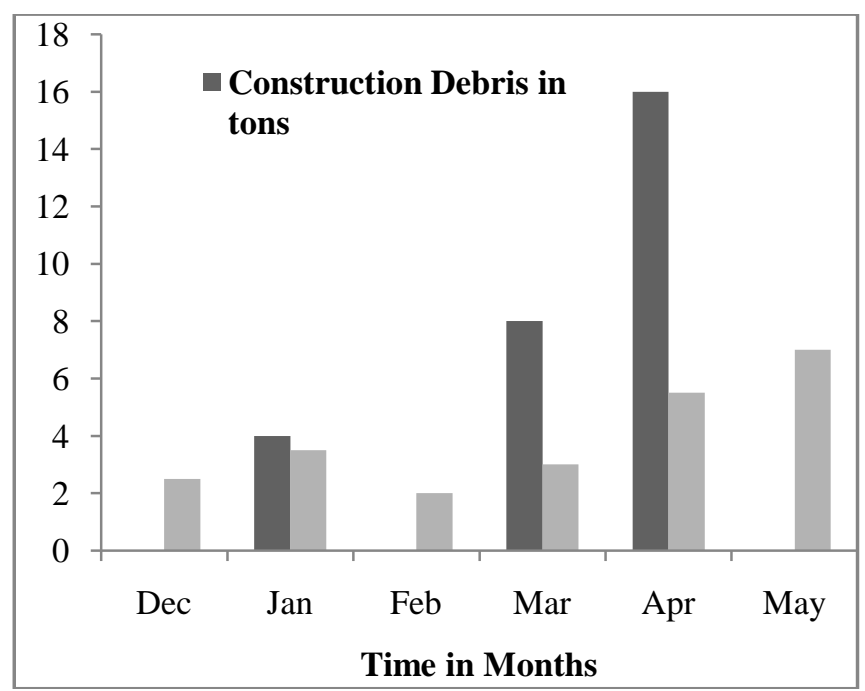

Chart-4: Construction debris and garden trimmings waste generation in GWA

The SHOWS-Scientific Handling of Waste Society, a decentralized compost plant is located in ward No.35 Aramane Nagara of Bangalore East zone. It started in the year 1992, with the corporation and Resident Welfare Association initiative. The land is given to the association to set up and run the compost plant catering to the waste generation from around 382 houses. As per the MOU the corporation sanctions an amount of Rs. 5 lakh/annum towards operation and maintenance of the plant. The food waste is put into the rectangular concrete tank and aerated by blowing air from the bottom for a period of 6weeks for proper maturation of the compost. For faster decomposition the days' waste will be mixed with commercially available EM culture powder. After maturation, the compost is sieved and stored for usage. Each tank will be covered with a tray containing charcoal to absorb bad odors. Chart -5 depicts the generation of compostable organic waste generation from SHOWS locality.

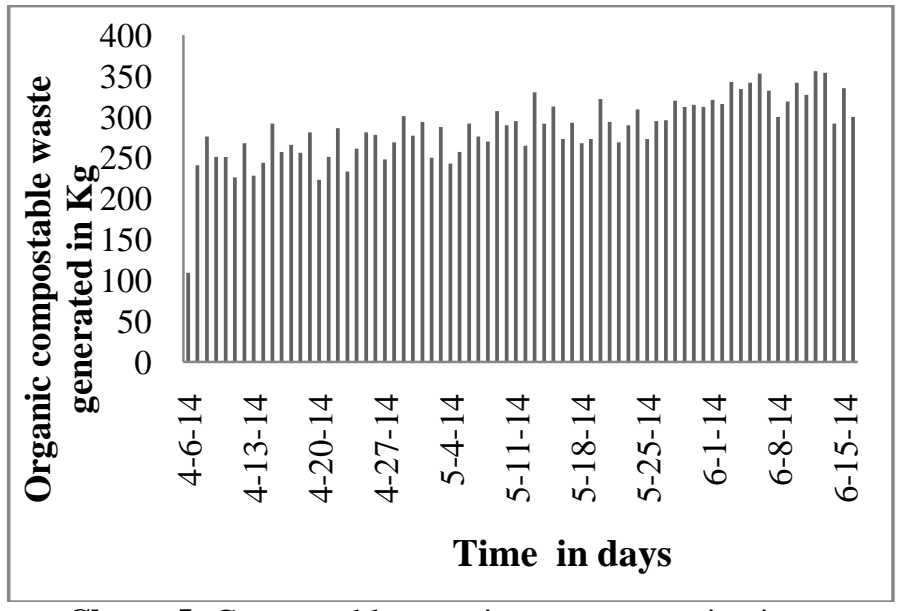

Chart- 5: Compostable organic waste generation in SHOWS locality.

The collection, segregation, recycling, and composting of the waste is completely managed by the association by employing their own crew. About $60 \mathrm{~kg}$ of recyclables consisting of PET bottles, newpapers, metal scrap, brass scrap materials, plastics, paper are generated per day; reject waste includes used tender coconuts, soiled plastics, thermacoal, soiled paper etc. which are handed over to the Corporation Lorries twice in a week. The waste recycler visits the plant everyday and purchases the recyclables, which serves as an additional income to the crew working there. An overview of the decentralized initiatives is presented in detail in Table-3.

Table -3: Overview of the Decentralized initiatives in Bengaluru City

\begin{tabular}{|c|c|c|}
\hline Components & GWA & SHOWS \\
\hline Total area in $\mathrm{m}^{2}$ & 279 & 370 \\
\hline $\begin{array}{l}\text { Total number of houses } \\
\text { covered }\end{array}$ & 600 & 382 \\
\hline $\begin{array}{l}\text { Total compostable } \\
\text { organic } \\
\text { generated/day in } \mathrm{Kg}\end{array}$ & 94 & 286 \\
\hline $\begin{array}{l}\text { Total recyclables } \\
\text { generated/day in } \mathrm{Kg}\end{array}$ & 135 & 110 \\
\hline $\begin{array}{l}\text { Total sanitary waste } \\
\text { generated per day in } \mathrm{kg}\end{array}$ & 42 & 25 \\
\hline $\begin{array}{l}\text { Total construction debris } \\
\text { collected/month in tons }\end{array}$ & 1.12 & Rarely obtained \\
\hline Manpower & 9 & 5 \\
\hline Source segregation & $40 \%$ & $50 \%$ \\
\hline $\begin{array}{l}\text { Total Capacity of } \\
\text { compost plant in } \mathrm{kg} / \mathrm{day}\end{array}$ & 150 & 325 \\
\hline Power capacity used & $5 \mathrm{HP}$ & $1 \mathrm{HP}$ \\
\hline $\begin{array}{l}\mathrm{O} / \mathrm{M} \text { cost of processing } \\
\text { plant }\end{array}$ & 35000 & 32000 \\
\hline $\begin{array}{ll}\text { Initial } & \text { Investment } \\
\text { Infrastructure in lakhs }\end{array}$ & 6 & 6.25 \\
\hline Processing methodology & $\begin{array}{l}\text { Processing in } \\
\text { Organic waste } \\
\text { converter, } \\
\text { followed by }\end{array}$ & $\begin{array}{l}\text { Organic } \\
\text { decomposition } \\
\text { in concrete } \\
\text { rectangular }\end{array}$ \\
\hline
\end{tabular}




\begin{tabular}{|l|l|l|}
\hline & $\begin{array}{l}\text { maturation in } \\
\text { plastic trays } \\
\text { for 4 weeks }\end{array}$ & $\begin{array}{l}\text { tanks with } \\
\text { constant for 6 } \\
\text { aeration for } \\
\text { weeks }\end{array}$ \\
\hline Compost resale value & Rs. 3/ Kg & Rs. 10/Kg \\
\hline $\begin{array}{l}\text { Profit/month through } \\
\text { sale of recyclables }\end{array}$ & $\begin{array}{l}\text { Rs.8000/ } \\
\text { month }\end{array}$ & $\begin{array}{l}\text { Rs.8000/ } \\
\text { month }\end{array}$ \\
\hline Land ownership & Own & $\begin{array}{l}\text { Given on Lease } \\
\text { by Bangalore } \\
\text { Corporation }\end{array}$ \\
\hline Market for compost & $\begin{array}{l}\text { Used within } \\
\text { their campus }\end{array}$ & $\begin{array}{l}\text { Used by their } \\
\text { locality people }\end{array}$ \\
\hline
\end{tabular}

\section{CONCLUSIONS}

As per the report by the Ministry of Urban Development department, Government of India the country will need 301 MMT of food grains by 2025 to feed 1.4 billion population. This will require the demand of chemical fertilizers (nutrients) to the extent of 35MMT in addition to around 10MMT from organic manure and bio-fertilizers. The existing availability of organic manure from all sources together is around 270-300 MMT, which may produce only 5-6 MMT of NPK nutrients [7]. Bengaluru city presently generates approximately $2500 \mathrm{Tons}$ of organic waste every day. From 2500tons of organic waste, after maturation period the total amount of compost obtained will be equal to 875tons/day @ of 35\% compost recovery. If more of decentralized initiatives are formalized and implemented at various parts of the city, it could actually produce a good quality compost of around 315000Tons annually, leading to a gross profit of 78.75 crores annually @ of Rs. 2500 per Ton of the compost sold.

\section{REFERENCES}

[1] Human Settlements Management Institute, New Delhi/WMC of UIFW, City wide best practices in solid waste management in collection, transportation and disposal, project paper No. 12, Sep, 1997.

[2] Bruhath Bengaluru Mahanagara Palike, Solid Waste Management Cell, available at www.bbmp.gov.in.

[3] Central Pollution Control Board, MoEF, Characterization of MSW compost and its application in agriculture, Control of Pollution Series: CUPS/59/2005-06.

[4] Christain ZurbrÜgg, Silke Drescher, Almitra Patel, H.C. Sharath Chandra, Decentralized composting of urban waste-an overview of community and private initiatives in Indian cities, Waste management, 24, 655-662, 2004.

[5] Time of India, $10^{\text {th }}$ October, 2012.

[6] Time of India, $4^{\text {th }}$ November, 2012.

[7] Inter-ministerial Task Force on Integrated Plant Nutrient Management using city compost, waste to wealth, Ministry of Urban Development department, Government of India, New Delhi, 2005.

\section{BIOGRAPHIES}

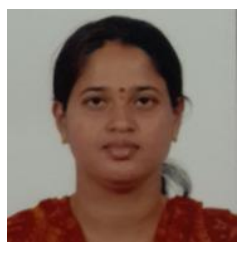

PAVAN, Assistant Professor, Department of Civil Engg, Sir M Visvesvaraya Institute of Technology, Karnataka, India, Main Research areas: Solid Waste Management, GIS, Remote Sensing. Email: pavansmvit@gmail.com

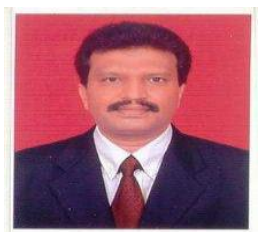

Dr. H. B. BALAKRISHNA, Professor, Department of Civil Engg, Bangalore Institute of Technology, Karnataka, India, Main research areas: Watershed management, remote sensing and GIS. Email: balubit@gmail.com 